\title{
Factors affecting customer satisfaction in banks and its relation to profitability A case study on a conventional bank and an Islamic bank
}

\author{
Yasser T. Halim, Ph.D. Associate Professor October \\ University for Modern Sciences and Arts \\ yassertawfik@,hotmail.com, ytawfik@msa.eun.eg
}

Samia A. Hanna El Sheikh, Ph.D. Lecturer of Marketing, October University for Modern Sciences and Arts selsheikh@msa.eun.eg

\begin{abstract}
Customer satisfaction is an important dimension for performance measurement for any organization. Customer satisfaction plays a key role in the banking sector as it is important for the development of a good relationship with customers which eventually affects the financial performance of banks. There has always been a challenge in identifying the criteria that should be used for customer satisfaction measurement, service quality in banks depends a lot on the employee professionalism especially for employees of customer service departments of banks. Moreover, excellent service quality is vital for business profitability and survival in banking sector. This research recommends measures that can be used to measure client satisfaction and evaluates its impact on the financial performance of banks in two types of private banks in Egypt, conventional banks and Islamic banks through studying a sample of bank clients in one of each type. This study shows customer satisfaction as a predictor of bank profitability. The purpose of this paper is to identify the main financial and non-financial aspects or factors that lead to customer satisfaction
\end{abstract}


in banking services and then to determine to what extent customer satisfaction affects the banks' profitability. Moreover, the research also investigates whether there is a difference in customer satisfaction factors in conventional banking from Islamic banking.

\section{Key Words}

Customer Satisfaction, Financial Performance, SERVQUAL, Service Profit Chain, Islamic Banking, Conventional Banking, profitability, Profit Margin, Return on Equity, Return on Investment.

\section{1-Introduction}

A brief historical study states that in 1960 the Central Bank of Egypt (CBE that is known as Bank Markazi) was established as a government bank that is responsible for issuing currency. In 1972 legislation further added the function of being responsible for national monetary policy. In the 1960s and 1970s, as the oil revenues increased in the Gulf region and this expanded the economic activities of the whole Middle East region that dealt mainly with Egypt, thus there was a great need for banking services in Egypt and the Arab World that resulted in having thirty six banks (twenty four commercial and twelve specialized) with 8,275 branches in Egypt by 1977.

However, by 1982, the number of banks were reduced to nine (six commercial and three specialized) and the branches were reduced to 6,581. In 1994, The Central Bank of Egypt approved the establishment of private credit institutions. In 1998 authorized foreign banks (many of which had already established representative offices in Cairo) started to offer full banking services in free-trade zones. (Central Bank of Egypt, (2016/2017), Annual Review Report.)

At present, according to the Central Bank of Egypt statistics, the banking sector in Egypt consists of 39 commercial banks 
and 3 Islamic Banks functioning in Egypt. Moreover, a few of the commercial banks have some Islamic deals.

Some of the main factors that led to an integrated banking industry are liberalization, deregulation and technological advancement. All resulted in creating a very competitive market place, that it becomes very crucial for banks to strive for improved services if they need to differentiate themselves from competition. Thus, it has become obligatory for the bank management to strive for customer satisfaction when using their resources. The significance of services as being the key factor in service products differentiation and gaining competitive edge resulted in very intense competition among banks (Shafie S., Azmi W., Haron S., 2004). Conventional banks' banking system has experienced major reforms since the 1990s. In fact, nowadays there is modernized and liberalized system which is managed and regulated according to internationally accepted standards (African Development Bank, (2009), "Conventional banks Private Sector Country Profile").

\section{Present situation:}

The banking sector in Egypt is facing a lot of challenges that include but not restricted to the following:

(1) Increased competition among private banks whether conventional or Islamic banks.

(2) Continuous shifts in regulatory environment due to the recent political and economic problems facing Egypt. Just to name a few are the floating of the Egyptian pound against the dollar and other tradable currencies, changes in investment rules and regulations restrictions on currency transfer and then removing the limitations on transfers of hard currency.

(3) The everlasting changes and advancements in technologies.

(4) Customer's requirements and sophistication are increasing rapidly as customers are becoming more and more 
demanding every day and more and more depending on the use of technology which provides the customers with endless information in the least possible timing.

(5) Increasing internationalization of financial products and financial institutions.

All these challenges put banks under stress to maintain their existing customers and to attract new ones. Customers are the core of any business and are considered main factor of starting or their lack is the reason for termination of the business. Hence they must be considered the masters of the market. Moreover, the business image, enhancement and eventually profits rely to a great extent on customer satisfaction. Therefore, it is extremely important for any business to meet and even exceed the client's expectations and thus achieve their satisfaction. As a matter of fact, financial performance of any organization can be enhanced by the client satisfaction

Customers are the most valuable assets in any organization. Therefore, it is essential for any business to know how to measure and assess customer satisfaction to explore ways to improve it and be able to run the business smoothly.

The purpose of this paper is to identify the main financial and non-financial aspects or factors that lead to customer satisfaction in banking services and then to determine to what extent customer satisfaction affects the banks' profitability. Moreover, the research also investigates whether there is a difference in customer satisfaction factors in conventional banking from Islamic banking.

\section{2-Research Problem}

The challenge facing banks is to maintain and increase the bank's profitability and this can be done by attracting new customers and retaining existing customers. This in turn, is based on customer satisfaction and even more, customer delight. The following two questions will clarify the main research problems: 
- How to measure customer satisfaction in banks and what are the financial and non-financial aspects that affect customer satisfaction?

- To what extent customer satisfaction affects the bank's profitability?

\section{3-Research Objectives}

The objectives of this research are:

1. To measure financial and non-financial factors related to customer satisfaction in banks through proposed measures.

2. To pinpoint the impact of customer satisfactions on banks profitability.

3.

\section{4-Research Hypotheses}

1. The financial and non-financial factors of customer satisfaction in banks can be assessed by the proposed measurements.

2. Improving customer satisfaction positively affects bank profitability.

\section{5-Literature Review}

\section{1-Customer Satisfaction}

As Kotler and Keller, (2012) mentioned that satisfaction is the feeling of pleasure versus disappointment resulted from the comparison between product's perceived performance to expectations. As for ways for measuring satisfaction, they mentioned several factors that identify satisfied customer behavior such as repurchase company's products, buys more as 
the company launches new and upgraded products, spreading good word of mouth about the company and its products, less responsive to competing brands and being less price sensitive, offering suggestions and recommendations to the company.

Customer satisfaction has always been considered an outstanding research topic among professional marketers and researchers of different areas. As a matter of fact, Banking is dealt with as one of the numerous industries in which customer satisfaction had an increasing significance in the corresponding research areas. This is mainly because the banking sector is becoming more competitive and customer oriented (Nasserzadeh et al., 2008).

It has been also found that higher customer satisfaction resulted in increasing the cross-selling at the branch level (Loveman 1998). Moreover, customer satisfaction proved to be an important indicator of sales and revenue, and growth in the customer base, in bank branches (Ittner and Larcker, 1998).

Nowadays, many financial services organizations are aiming to be customer focused. Customer satisfaction turned out to be an important aspect for performance measurement for banking and finance industry. Since most financial organizations and banks offer similar products and services, increasing customer satisfaction and customer loyalty are the most crucial distinguishable factors in maintaining and increasing market share for these firms (Muhammad and Monir 2011). Gomeza, McLaughlinb and Wittinkc, (2004) stated that customer satisfaction acts as a key element in a successful business strategy. The ability of the bank as a service provider to generate high degree of satisfaction is crucial for products differentiation and development of strong relationship with customers (Deng et al., 2009).

Because customers do not easily express their demands thus this poses a difficulty in measuring this construct. When reviewing 
literature related to customer satisfaction, the two most frequent customer satisfaction theories handled were the profit chain based on the work of Heskett et al., (1994) and SERVQUAL based on Parasuraman et al., (1985).

\subsection{1-First: Service profit chain and its application on banks:}

The service profit chain, that first mentioned by Heskett et al., (1994), offers one of the most important perspectives on customer satisfaction issue. According to the service profit chain, service quality is determined by employee satisfaction that is the main reason for growth and profit. The original proposals were supported by a research in twenty large service organizations and other successive researches have resulted in proving the same relationships (Anderson and Mittal, 2000). In short, the service profit chain proposes a direct link between staff satisfaction, service quality and customer satisfaction stressing that staff satisfaction is a direct reason for customer satisfaction. Moreover, customer satisfaction leads to profitability. (Harry Maddern, Roger Maull, Andi Smart, and Paul Baker, 2007). 


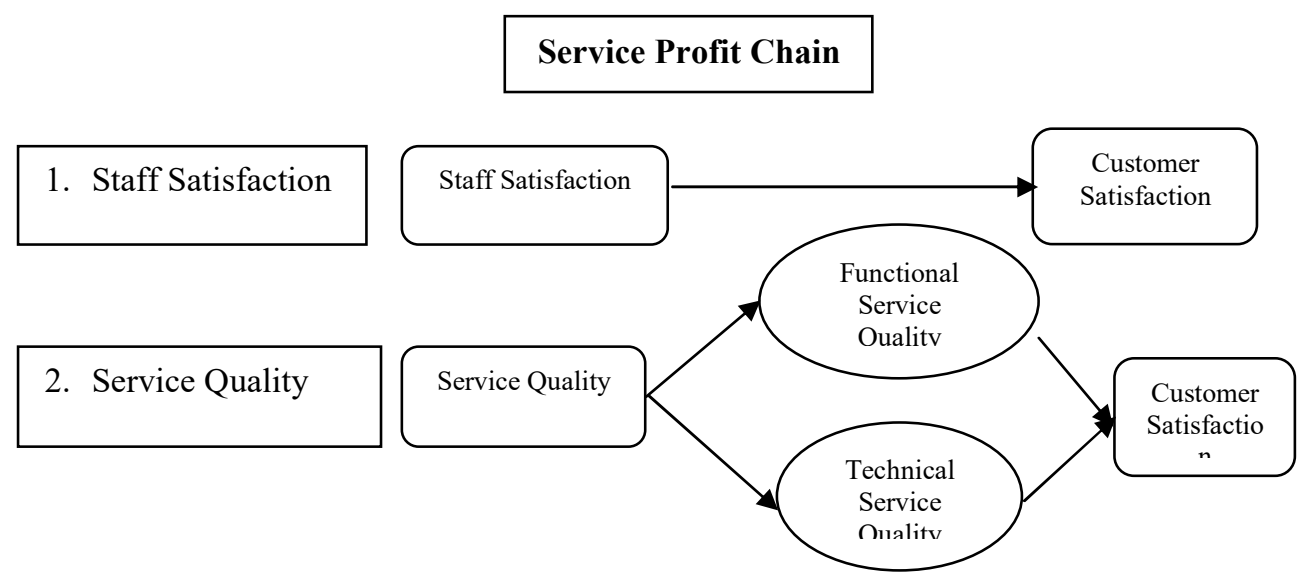

Source: Harry Maddern, Roger Maull, Andi Smart, and Paul Baker (2007).

\subsection{2-Second: SERVQUAL:}

SERVQUAL has the same aim which is to determine the determinants of customer satisfaction. The original dimensions of SERVQUAL were at first 10 dimensions which were reduced to 5 dimensions which are assurance, reliability, tangibles, empathy and responsiveness. (Munu Samy, Chelliah and Mun, 2010). Yet, according Maddern, Maull and Smart (2007) recently some researchers question both theories. With regards to service profit chain, the simple linear relationship was questioned by Andreson and Mitlal, (2000).

Moreover, Silvestro and Cross (2000) throw more questioning regarding the strength of the relationship. On the other hand, SERVQUAL which in fact is the most widely employed theory in customer satisfaction literature yet it was also criticized in certain papers because it emphasizes the functional quality of the service soft factors as Curtsey and Smilirg rather than the technical 
aspect which could be the true source of dissatisfaction of the customer with the service as not meeting the promises made to the customer. (Jhonston, 1995).

Bank management must work on identifying and improving factors and reasons that can put an end to customer dissatisfaction. These include many factors such as employee professionalism, performance and, ability and willingness to solve problems, level of knowledge, friendliness in communication and selling skills. Furthermore, customer dissatisfaction can also be reduced through adjusting bank's rates, fees, policies and better branches locations (Leeds, 1992).

One of the most important challenges is identifying the criteria that can be used for satisfaction measurement. More studies in developing world showed a clear relation between customer satisfaction and service quality (Reaz, M., Arun, T. 2006). Although there are several studies that emphasized the importance of retaining customer in the banking industry, little effort was exerted to explore the reasons that might have led to customer dissatisfaction or satisfaction (Fisher, 2001). The majority of researches that were published focused on its effect without any attempt to connect them to a model to investigate retention. While if retention criteria are not well assessed and measured, customers will still leave their banks, regardless of all the efforts and trials of bankers to retain them. A key factor of improved customer focus is the implementation of tools that allow developing better relations between banks and their customers (customer-bank relationship) (Marvin E., et al., 2004).

Based on the literature review and in-depth interviews that the researchers conducted to get a notion from bank managers as what they feel are true factors affecting customer satisfaction, the researchers resorted to a group of 
measures, some of which are financial in nature and some are non-financial.

The following table shows the suggested variables that the researchers proposed to use to measure customer satisfaction within the selected banks, one of which is a conventional bank and the other an Islamic bank.

Table (1): The Proposed Factors that affect Customer Satisfaction in Banks

1. Speed of service -Timeliness - Responsiveness (SERVQUAL)

2. Knowledge of Customer service employees -accuracy(SERVQUAL)

3. Waiting area-Tangibles (SERVQUAL)

4. Politeness \& Respect of Customer service employees-(SERVQUAL)

5. Variety of banking products

6. High Productivity of workers (Service Chain)

7. Convenient Business Hours-Responsiveness (SERVQUAL)

8. Parking area outside-Tangibles (SERVQUAL)

9. E-banking- Tangibles/Reliability (SERVQUAL)

10. Appearance of the branch-Tangibles (SERVQUAL)

11. Bank Amenities (Financial Aspects)

12. Response to customer's problems and queries(SERVQUAL) 
13. Equipment used - Tangibles (SERVQUAL)

14. Availability of Safe boxes - Tangibles (SERVQUAL)

15. Bank advertisements

16. Availability of branches

17. Call Center performance

18. International bank deals

19. The rate of satisfaction with SMS service

20. Interest rate (Financial Aspects )

21. The rate of banking profit for customer(Financial Aspects )

22. Complaint management

23. Phone banking

24. Safety measures-Assurance (SERVQUAL)

25. Minimum paper work

26. Trustful Billing (Financial)

27. Cost of Service(Financial Aspects )

28. ATM service-Tangibles (SERVQUAL)

\section{2-Customer Satisfaction and its Relation to Profitability}


The quality of presenting a service has been reported to have a relationship with profitability in some researches as in Rust and Zahork (1993); Zahorik and Rust, (1992); Sachdev and Verma, (2004).

Moreover, customer satisfaction also has an impact positive word of mouth which ultimately lead to organizational strategic goals as increased market share and return on investment as in Sachdev and Verma, (2004).

Thus, in this competitive world, it is unacceptable for any organization to be non-customer-oriented. In fact, organizations have to produce high quality products and services that results in highly satisfied and loyal customers (Fecikova, 2004). For decades, customer satisfaction has always become the major goals of business organizations since it affects customer retention and companies' market share (Hansemark and Albinsson, 2004). Commonly, satisfied clients are loyal clients who are less-price sensitive and less influenced by competition (Dimitriades, 2006). Although it seems costly to obtain loyal and satisfied customers, it proved to be profitable in the long run for any firm (Anderson, Fornell and Mazvancheryl, 2004). Consequently, the firm should focus on improving service quality and charging appropriate convenient price to retain and satisfy its customers (Gustafsson, Johnson and Roos, 2005).

Levesque and McDougall, (1996) classified the information and details that could be generated after measuring customer's satisfaction to business related and financial related outcome. As for business related outcome, measuring customer satisfaction helps in identifying the efficiency of the organization business strategies and marketing tactics and detects whether it is customer focused or not. Moreover, it also provides information on the numbers of customers have faced defects, and information about any loss the business has incurred and how much the profit is affected due to customer defect. For instance, 
a customer is usually dissatisfied when the organization didn't meet his expectations. In other words, loss of customers is directly in proportion to loss of business and profitability. In short, if an organization can measure business related aspects of customer satisfaction then it becomes able to bridge the gaps between them and their customers and accordingly develop more customer satisfaction. As for Financial related outcome, since the financial performance is one of the hot issues nowadays and is applicable to all types of the businesses and especially banks taking into consideration the special nature of banks operations. The banks try to maintain old clients and attract new clients and of course this can be of great outcome on the profitability and financial performance of the banks.

Evaluating the bank profitability is a complicated process that involves measuring the interaction between the internal operations, external activities and the environment. It was found that there is mutual two ways link and relationship between profitability and customer satisfaction. A key management element that many studies have found to be a primary factor in assessing bank profitability is operating efficiently which leads to customer satisfaction. Customer satisfaction also leads to

profitability. Customer satisfaction can increase cross selling and the number of customers in the bank. On the other hand, worth to mention that customers are not the same as one particular customer generates different costs and revenues over time from another customer. In other words, not every customer generates satisfactory cost or revenue streams. For example, in retail banking, sixty percent of customers might be unprofitable (Storbacka et al., 1994). It is recommended, therefore, that the bank should work on activating the relationships and the link with profitable customers by personalized relationship and special treatments to high affluent clients and plan to end 
relationships with unprofitable customers (Peppers \& Rogers 1997).

Direct relationship between good service and improved financial performance has been emphasized by Roth and Van Der Velde (1991) and Bennet (1992). Moreover, Bowen and Hedges (1993) recognized that quality of service improvement is directly linked to market share expansion.

Figure (2) The Proposed Measures of Profitability

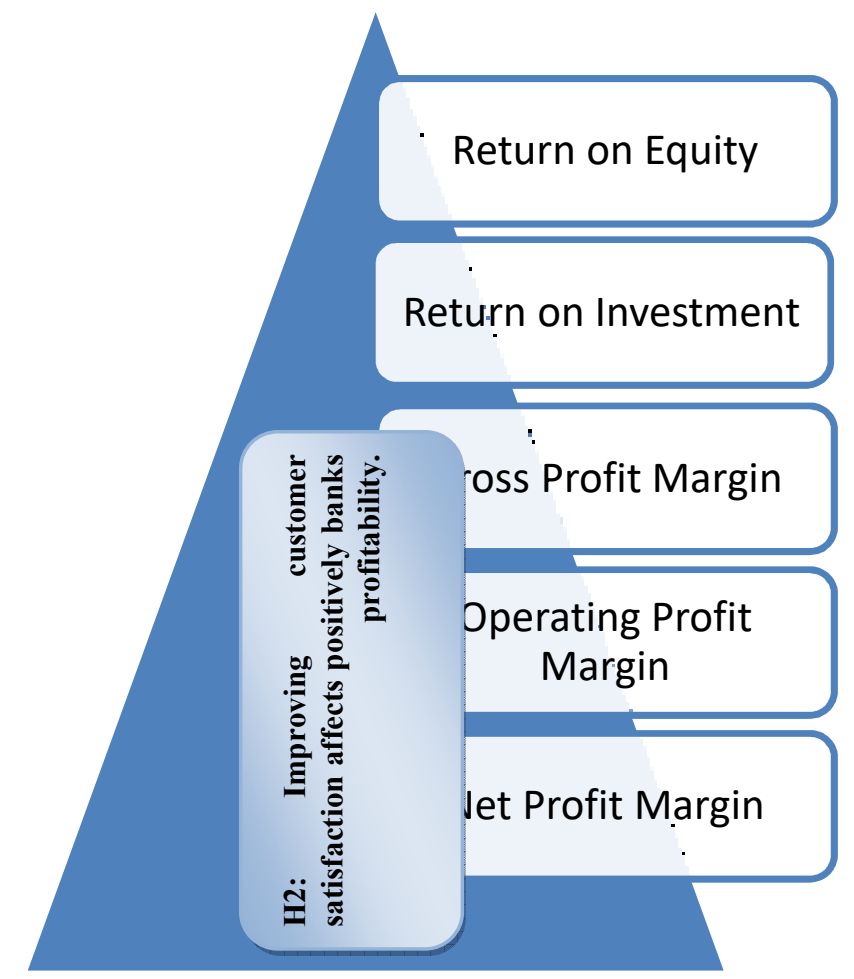

\section{6-Methodology}


6.1-The researchers resorted to the case study approach which is quite useful in case of exploratory research as is our case as the researchers were developing a mixture of factors affecting bank customers satisfaction based on a combination of factors from previous literature as well as factors taken from the indepth interviews conducted with the bank managers.

6.2-The researchers conducted 4 long structured in-depth interviews with top level bank managers that were selected conveniently due to knowledge of these managers in two banks a conventional bank which is Qatar National Bank Al Ahli (QNB Al Ahli) and an Islamic bank which is Al Baraka Bank Egypt.

\section{3-A brief history about both banks:}

\subsection{1-Qatar National Bank Al Ahli (QNB Al Ahil):}

According to the website of the bank, it is one of the largest private banks operating in Egypt. It was established in 1972 and currently it has more than one million clients. It offers a wide range of products serving individuals, corporation and small and medium enterprises. QNB Al Ahil has 215 branches covering all the governorates of Egypt and 450 ATMs. Furthermore, it has a dedicated customer service call center which is available 24 hours a day, 7 days a week. (www.qnbalahli.com)

\subsection{2-Al Baraka Bank Egypt:}

According to the website of the bank, Al Baraka Bank Egypt managed to secure its position in the banking sector of Egypt with a variety of services and products and is considered as a pioneer Islamic institution in the Egyptian market. All services provided by the bank conform to the provisions of Islamic Sharia. The bank has now 27 branches distributed among 
Egypt's governorates and major cities. There are 5 more branches under construction to further serve various locations in Egypt. Al Baraka bank Egypt is considered one of tributaries of Al Baraka Banking Group (ABG) with headquarters in Bahrain. The group is considered among pioneers in Islamic banking not only in the Arab World but in the world. The authorized capital of the group is US\$ 1.5 billion and total shareholder's equity of approximately US\$2 billion. (www.albarakabank.com.eg/about/.aspx)

6.4-A data collection tool which is a self- administered questionnaire was designed and directed to a convenient sample of customers in both banks conventional bank (QNBALAHLI), and (Islamic Bank) Al Baraka bank, to get information on the relationships between customer satisfaction measures and bank profitability.

6.5-A judgmental sample included 240 questionnaires were distributed to customers of both bank. The response from QNB Al Ahli reached approximately 209 and 11 questionnaires were excluded, with response rate of $82.5 \%$, while Al Baraka Bank response reached approximately 175 and 4 questionnaires were excluded, with response rate of $71.25 \%$.

6.6-Data obtained was analyzed by using Statistical Package for Social Sciences (SPSS). Frequencies and percentages were made for all the questions, a combination of different techniques were used including descriptive statistics, discriminate analysis and factor analysis.

\section{7-Statistical Analysis Results and Discussion:}

\section{1-Testing the Reliability:}

To test the reliability of results the researchers used Cronbach alpha which is most widely used test of reliability. 
Table (2): Reliability Test:

\begin{tabular}{|c|c|c|c|c|c|}
\hline Type & & $\mathrm{N}$ & Mean & $\begin{array}{c}\text { Std. } \\
\text { Deviation }\end{array}$ & $\begin{array}{c}\text { Cronbach's } \\
\text { Alpha }\end{array}$ \\
\hline $\begin{array}{c}\text { 1. Conventional } \\
\text { banks }\end{array}$ & Satisfaction & 209 & 3.4759 & 0.47240 & 0.902 \\
\hline 2. Islamic banks & Satisfaction & 171 & 3.5021 & 0.47283 & 0.889 \\
\hline
\end{tabular}

Testing the reliability of all latent construct, the measurement in table (2) showed that they are reliable. The Cronbach's Alpha for all the latent constructs and measurements is 0.902 in Conventional banks and 0.889 in Islamic banks. Furthermore, the Cronbach's Alpha for all the measurements showed to be more than 0.7. This means that the results of the test are reliable as Cronbach's Alpha suggested. (Hair, et al 2010)

\section{2-Testing Hypothesis 1:}

\section{Factor Analysis:}

Confirmatory Factor Analysis (CFA) has been conducted to test the validity which is the degree to which the measures accurately represent what it is supposed to. The data matrix for each measure should have adequate correlations in order to justify the application of factor analysis. 
Dr Yasser T. Halim.- Dr. Samia A. El Sheikh 2/10/2018

Figure (3): Confirmatory analysis Conventional banks
Table (3): Confirmatory

Factor analysis

(Conventional banks)

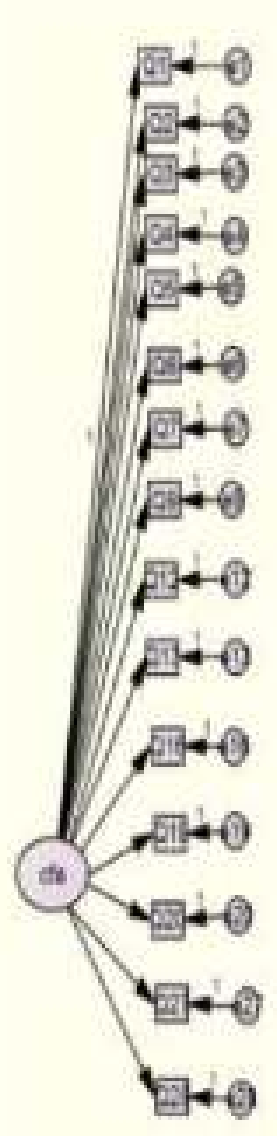

\begin{tabular}{|c|c|c|c|c|}
\hline & Estimate & $\begin{array}{c}\text { Standard } \\
\text { Error } \\
\text { (S.E.) }\end{array}$ & $\begin{array}{c}\text { Critical } \\
\text { Ratio } \\
\text { (C.R.) }\end{array}$ & $\mathbf{P}$ \\
\hline Q1 <--- cfa & 1.000 & & & \\
\hline Q2 <--- cfa & 1.169 & .122 & 9.551 & $* * *$ \\
\hline Q3 <--- cfa & 1.456 & .145 & 10.050 & $* * *$ \\
\hline Q4 <--- cfa & 1.209 & .122 & 9.914 & $* * *$ \\
\hline Q5 <--- cfa & 1.235 & .118 & 10.447 & $* * *$ \\
\hline Q6 <--- cfa & 1.132 & .114 & 9.908 & $* * *$ \\
\hline Q7 <--- cfa & 1.174 & .119 & 9.903 & $* * *$ \\
\hline Q9 <--- cfa & 1.134 & .130 & 8.744 & $* * *$ \\
\hline Q12<--- cfa & .987 & .108 & 9.136 & $* * *$ \\
\hline Q13<--- cfa & 1.309 & .135 & 9.686 & $* * *$ \\
\hline Q16 <--- cfa & .740 & .108 & 6.843 & $* * *$ \\
\hline Q19<--- cfa & 1.115 & .119 & 9.339 & $* * *$ \\
\hline Q20 <--- cfa & 1.139 & .136 & 8.378 & $* * *$ \\
\hline Q27 <--- cfa & .906 & .109 & 8.311 & $* * *$ \\
\hline Q28<--- cfa & 1.292 & .133 & 9.699 & $* * *$ \\
\hline
\end{tabular}

The confirmatory factor analysis in Conventional bank Table (3) is conducted to test how well the measured variables represent the constructs. Figure (3) shows the measures used in the analysis 
which were initially considered to measure the effect of customer satisfaction on banks profitability in the Conventional bank. The construct validity is the extent to which a set of measured items actually measures the construct. This has been computed in the (CFA). Variables shown in table (3) were found to be valid.

\begin{tabular}{|c|c|c|c|}
\hline -Chi-Square & 425.07 & - Normed Fit Index (NFI) & 0.965 \\
\hline -Degree of Freedom & 90 & -Relative Fit Index (RFI) & 0.955 \\
\hline -Level of Significance & 0.000 & - Tucker Lewis Index (TLI) & 0.965 \\
\hline -Normed Chi-Square & 4.723 & $\begin{array}{c}\text {-Comparative Fit Index } \\
\text { (CFI) }\end{array}$ & 0.979 \\
\hline $\begin{array}{l}\text {-Root Mean Square Residual } \\
\text { (RMR) }\end{array}$ & 0.041 & $\begin{array}{c}\bullet \text { Root Mean Square } \\
\text { Residual }\end{array}$ & 0.044 \\
\hline - Goodness of Fit Index (GFI) & 0.918 & & \\
\hline $\begin{array}{c}\text { - Adjusted Goodness of Fit } \\
\text { Index (AGFI) }\end{array}$ & 0.918 & Approximation (RMSEA) & \\
\hline
\end{tabular}

Table (4) shows the Chi-square value of the research model is 425.07 and $\mathrm{P}=0.000$ suggesting that the hypothesized model's fit to data is inadequate. Yet, some researchers divide the Chi-square by the numbers of degrees of freedom. A rule of thumb is that if this ratio is less than 5 it is acceptable. The normed Chi-square is 4.723 which is less than 5. However, the literature on model fit indices, reports various other indices that should be utilized to reflect the model fit than the Chi-square statistics (Fong, et al., 2007; Daire, et al., 2008). The goodness of fit indices are within the acceptable values that approaches the value of one and that indicates the quality of the measures. Table (4) clarifies that there is adequate convergent 
validity, and all goodness of fit tests of the model showed significant results.

Figure (4):

Confirmatory

analysis Islamic

banks.
Table (5): Confirmatory Factor analysis (Islamic banks)

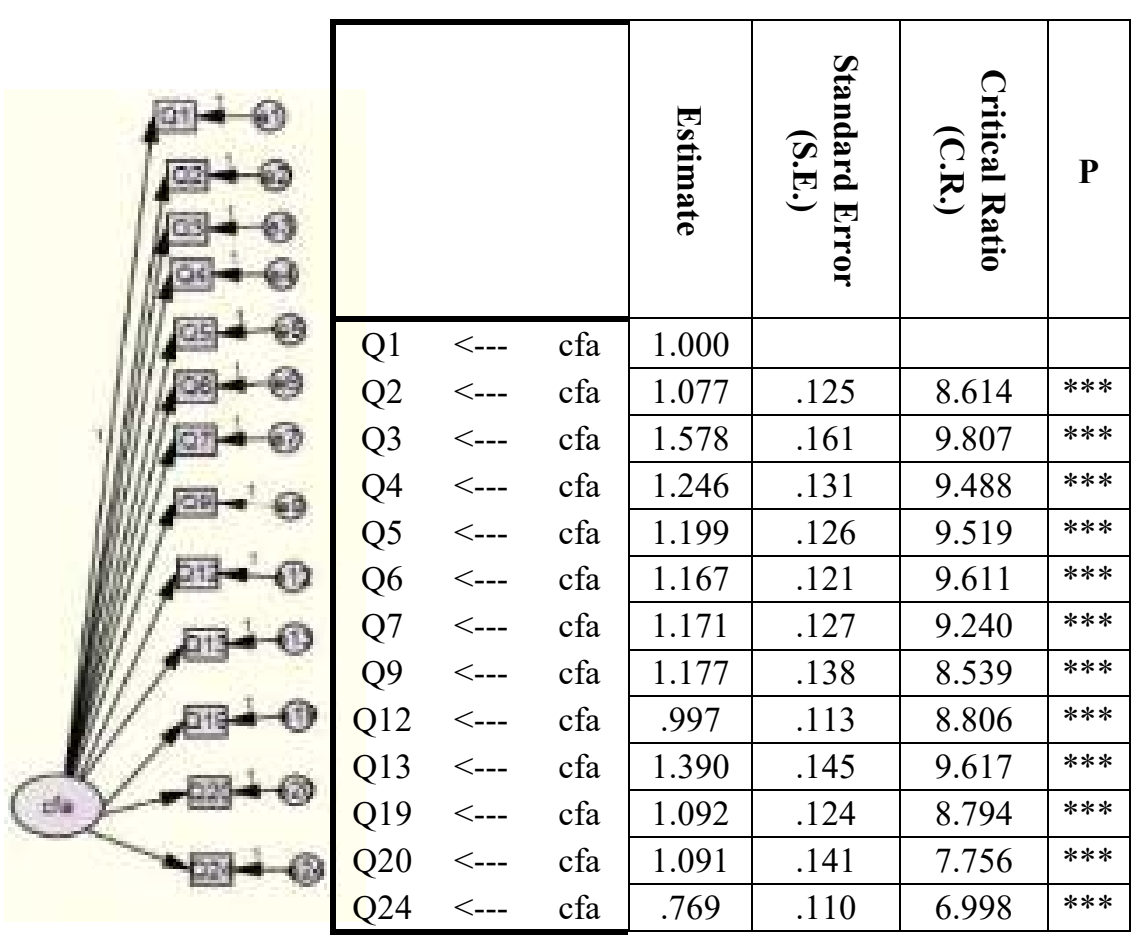

The confirmatory factor analysis in Islamic bank Table (5) is conducted to test how well the measured variables represent the constructs and to verify the results of the regression analysis. Figure (4) shows the measures used in the analysis which were initially considered to measure the effect of customer 

construct validity is the extent to which a set of measured items actually measures the construct. This has been computed in the (CFA). Variables shown in table (5) were found to be valid.

Table (6): The Goodness of Fit Indices in the Confirmatory Factor Analysis

\begin{tabular}{|c|c|c|c|}
\hline -Chi-Square & 319.475 & $\begin{array}{c}\text { - Normed Fit Index } \\
\text { (NFI) }\end{array}$ & 0.982 \\
\hline -Degree of Freedom & 65 & $\begin{array}{l}\text { - Relative Fit Index } \\
\text { (RFI) }\end{array}$ & 0.904 \\
\hline -Level of Significance & 0.000 & $\begin{array}{l}\text { - Tucker Lewis Index } \\
\text { (TLI) }\end{array}$ & 0.972 \\
\hline •Normed Chi-Square & 4.915 & $\begin{array}{c}\text {-Comparative Fit Index } \\
\text { (CFI) }\end{array}$ & 0.980 \\
\hline $\begin{array}{l}\text {-Root Mean Square Residual } \\
\text { (RMR) }\end{array}$ & 0.040 & $\begin{array}{c}\bullet \text { Root Mean Square } \\
\text { Residual }\end{array}$ & 0.054 \\
\hline • Goodness of Fit Index (GFI) & 0.952 & & \\
\hline $\begin{array}{l}\text {-Adjusted Goodness of Fit Index } \\
\text { (AGFI) }\end{array}$ & 0.910 & $\begin{array}{l}\text { Approximation } \\
\text { (RMSEA) }\end{array}$ & \\
\hline
\end{tabular}

Table (6) shows the Chi-square value of the research model is 319. 475 and $P=0.000$ suggesting that the hypothesized model's fit to data is inadequate. Yet the normed Chi-square is 4.915 which is less than 5 thus acceptable. However, the literature on model fit indices, reports various other indices that should be utilized to reflect the model fit than the Chi-square statistics (Fong, et al., 2007; Daire, et al., 2008). The goodness of fit indices are within the acceptable values that approaches the value 

(6) clarifies that there is adequate convergent validity, and all goodness of fit tests of the model showed significant results.

\section{Discussion}

From the CFA, factors 8, 10, 11, 14, 15, 17, 18, 21, 22, 23, 25, 26 (they are lightly shaded in table (1) are cancelled from both conventional bank and Islamic bank thus they are less important in customer satisfaction which eventually leads to bank profitability.

Moreover, there are factors that were accepted in conventional banks as but not in Islamic banks as factors 16, 27 and 28 and one factor that was accepted by Islamic bank but not by conventional banks as factor 24

Thus it can concluded that after removing the factors that were rejected by CFA the measurement tool can be used to measure the factors that can affect customer satisfaction in the banking sector. Thus we can conclude the following:

1- Of the Financial aspects that were included as a result of the in-depth interviews only the interest rates was high enough on loading and thus is considered an important financial factor. Moreover, Cost of Service (Financial Aspects) was important for conventional bank but not for Islamic banks.

2- Of the service chain theory only one factor happens to be highly important and leads to satisfaction of customers which is High productivity of the workers.

3- Most of the SERVQUAL factors are highly important for customer satisfaction including: Speed of the service, Knowledge and competence of the employees, politeness and respect of employees, Equipment used - Tangibles 
(SERVQUAL), Responses to customer's problems and queries,(SERVQUAL), ATM service-Tangibles (SERVQUAL). This support the theoretical base of SERVQUAL theory which is still very valid for customer satisfaction.

4- After removing the factors that were rejected by CFA the measurement tool can be used to measure the factors that can affect customer satisfaction in the banking sector.

\section{Thus H1 is accepted}

\section{3- Testing Hypothesis 2}

Table (7): Descriptive statistics

\begin{tabular}{|c|c|c|c|c|}
\hline Type & & Mean & Std. Deviation & $\mathrm{N}$ \\
\hline \multirow{2}{*}{1.00} & PROFITABILITY & 3.70 & 0.664 & 209 \\
\cline { 2 - 5 } & SATISFACTION & 3.6259 & 0.55660 & 209 \\
\hline \multirow{2}{*}{2.00} & PROFITABILITY & 3.71 & 0.699 & 171 \\
\cline { 2 - 5 } & SATISFACTION & 3.6401 & 0.59966 & 171 \\
\hline
\end{tabular}

Table (7) shows the tendency of the respondent's answers toward the effect of satisfaction on profitability in Conventional bank (Type 1) and Islamic bank (Type 2) as it is indicated by the mean and standard deviation values. 
Table (8): Pearson Correlation.

\begin{tabular}{|c|c|c|c|c|c|}
\hline Type & & & 党 & 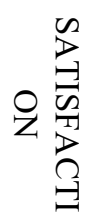 & 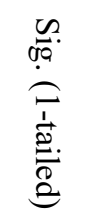 \\
\hline \multirow{2}{*}{1} & \multirow{2}{*}{$\begin{array}{c}\text { Pearson } \\
\text { Correlation }\end{array}$} & PROFITABILITY & 1.000 & 0.641 & 0.000 \\
\hline & & SATISFACTION & 0.641 & 1.000 & 0.000 \\
\hline \multirow{2}{*}{2} & \multirow{2}{*}{$\begin{array}{c}\text { Pearson } \\
\text { Correlation }\end{array}$} & PROFITABILITY & 1.000 & 0.670 & 0.000 \\
\hline & & SATISFACTION & 0.670 & 1.000 & 0.000 \\
\hline
\end{tabular}

***Parameter is significant at the (.001) level

Table (8) shows the correlation between the satisfaction and the profitability in banks where the Pearson Correlation value is 0.641 for Conventional bank (Type 1) and 0.670 for Islamic bank (Type 2) at significant level 0.001 . Thus $\mathbf{H 2}$ is accepted Table (9): F-Test result

\begin{tabular}{|c|c|c|c|}
\hline TYPE & R Square & F & Sig. \\
\hline 1.00 & 0.411 & 144.495 & 0.000 \\
\hline 2.00 & 0.449 & 137.818 & 0.000 \\
\hline
\end{tabular}

***Parameter is significant at the (.001) level

Table (9) shows the $\mathrm{R}$ Square for the proposed variables presented by the researchers. R Square values indicated that almost $41 \%$ and $45 \%$ in Conventional bank (Type 1) and Islamic bank (Type 2) profitability are explained by the proposed factors for increasing customer satisfaction.

The table included also F-test results that indicated the goodness of fit of the model that will be presented by the researchers to show the effect of the satisfaction on the profitability of the banks in the two types. 
Factors affecting customer satisfaction

Dr Yasser T. Halim.- Dr. Samia A. EI Sheikh 2/10/2018

Table (10): Regression analysis

\begin{tabular}{|c|c|c|c|c|c|}
\hline \multirow{2}{*}{ Type } & & \multicolumn{2}{|c|}{$\begin{array}{c}\text { Un-standardized } \\
\text { Coefficients }\end{array}$} & \multirow{2}{*}{$\mathrm{t}$} & \multirow{2}{*}{ Sig. } \\
\cline { 3 - 4 } & & $\beta$ & Std. Error & & \\
\hline \multirow{2}{*}{1.00} & (Constant) & 0.931 & 0.233 & 3.993 & 0.000 \\
\cline { 2 - 5 } & SATISFACTION & 0.764 & 0.064 & 12.021 & 0.000 \\
\hline \multirow{2}{*}{2.00} & (Constant) & 0.871 & 0.245 & 3.552 & 0.000 \\
\cline { 2 - 4 } & SATISFACTION & 0.781 & 0.067 & 11.740 & 0.000 \\
\hline
\end{tabular}

Table (10) shows the regression model for Conventional bank (Type 1) and Islamic bank (Type 2) for calculating the profitability based on customer satisfaction, where $\beta$ 's are statistically significant at level 0.000 , as illustrated in the next formulas:

Conventional banks Islamic banks

Profitability

$=0.931+0.764$

Profitability

Satisfaction

$=0.871+0.781$

Satisfaction 
Figure (5): Normal P-P

Plot of Regression Unstandardized Residual for

Conventional banks

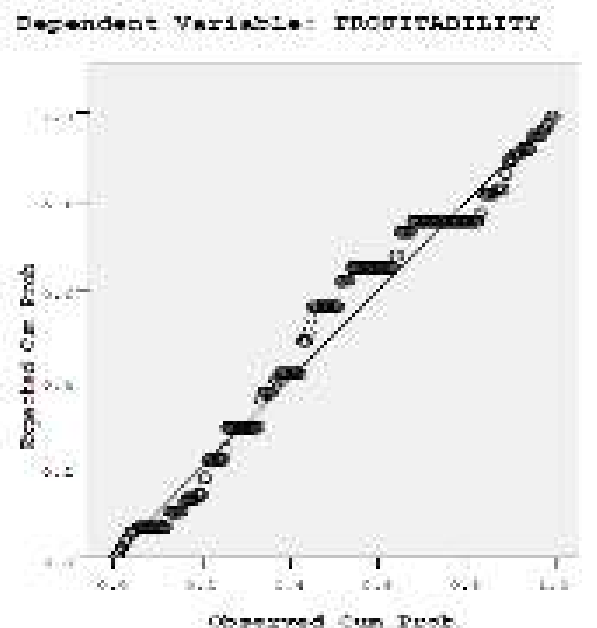

Figure (6): Normal P-P Plot of Regression Unstandardized Residual for Islamic banks

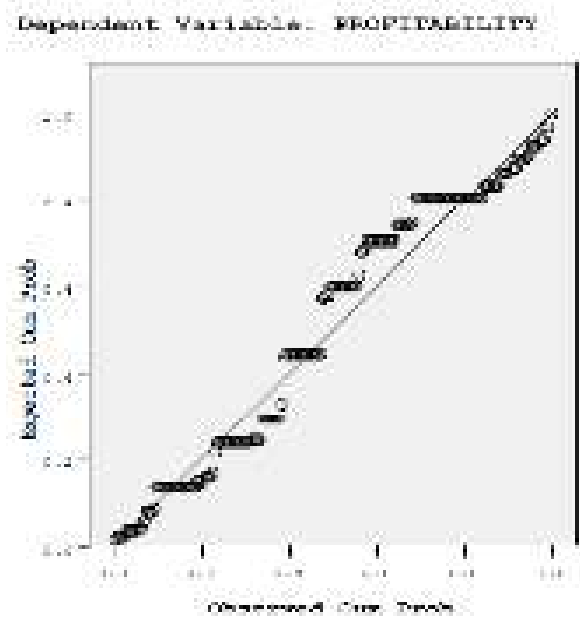

Figures (5) and (6) illustrate graphically the Normal Plot of Regression Un-standardized Residual for Conventional banks and Islamic banks respectively. The graphs show that the expected cumulative probability is not in great variance from the observed cumulative probability. This indicates the validity of the regression model and the measures components of this model and its great effect on the profitability through enhancing the customer satisfaction.

Table (11): Stepwise Regression

\begin{tabular}{|c|c|c|c|}
\hline Type & R Square & F & Sig. \\
\hline 1.00 & 0.532 & 57.995 & 0.000 \\
\hline 2.00 & 0.479 & 38.195 & 0.000 \\
\hline
\end{tabular}

***Parameter is significant at the (.001) level 
Factors affecting customer satisfaction

Dr Yasser T. Halim.- Dr. Samia A. El Sheikh 2/10/2018

Table (11) shows the R Square values for the effect of the five significant measures. It indicates that these variables explain almost $53 \%$ and $48 \%$ factors to affect profitability in Conventional banks and Islamic banks respectively. 
Table (12): Regression model for Conventional banks and Islamic banks

\begin{tabular}{|c|c|c|c|c|c|c|c|c|c|}
\hline \multicolumn{5}{|c|}{ Conventional banks } & \multicolumn{5}{|c|}{ Islamic banks } \\
\hline \multirow{2}{*}{ 兽 } & \multicolumn{2}{|c|}{ 占 } & \multirow[t]{2}{*}{$\mathbf{t}$} & \multirow[t]{2}{*}{$\dot{000}$} & \multirow{2}{*}{ 兽 } & \multicolumn{2}{|c|}{ 占点 } & \multirow[t]{2}{*}{$\mathbf{t}$} & \multirow[t]{2}{*}{$\ddot{\Delta 0}$} \\
\hline & $\boldsymbol{\beta}$ & 总 & & & & $\boldsymbol{\beta}$ & 完 & & \\
\hline 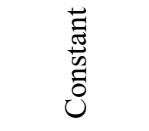 & 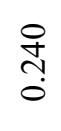 & กิ & స్త & 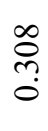 & 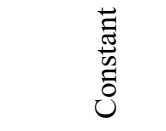 & 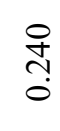 & กิ & $\bar{\Xi}$ & 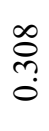 \\
\hline 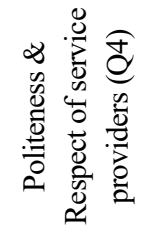 & $\begin{array}{l}\overline{6} \\
\text { ஸे }\end{array}$ & $\begin{array}{l}0 \\
0 \\
0 \\
0\end{array}$ & $\begin{array}{l}0 \\
\text { a } \\
\text { m. }\end{array}$ & $\begin{array}{l}8 \\
8 \\
0\end{array}$ & 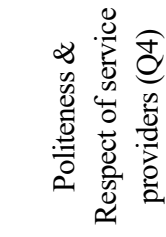 & $\begin{array}{l}\bar{b} \\
\text { ஸे }\end{array}$ & $\begin{array}{l}0 \\
0 \\
0 \\
0\end{array}$ & $\begin{array}{l}0 \\
\text { वे } \\
\text { mं }\end{array}$ & $\begin{array}{l}8 \\
8 \\
0\end{array}$ \\
\hline 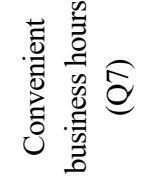 & กิ & $\begin{array}{l}\infty \\
\stackrel{0}{n} \\
0 \\
0\end{array}$ & $\begin{array}{l}\text { 芯 } \\
6 \\
\dot{1}\end{array}$ & $\begin{array}{l}8 \\
8 \\
0\end{array}$ & 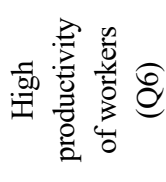 & ָ̃ & $\begin{array}{l}\infty \\
\stackrel{n}{0} \\
0\end{array}$ & $\begin{array}{l}\text { \& } \\
0 \\
\dot{0} \\
i\end{array}$ & $\begin{array}{l}8 \\
8 \\
0\end{array}$ \\
\hline 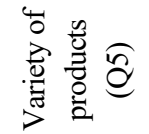 & $\bar{I}$ & 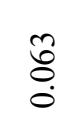 & $\frac{ \pm}{i}$ & '̊̊̊ & 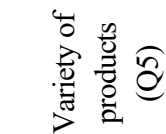 & $\frac{7}{0}$ & $\begin{array}{l}0 \\
\varrho \\
0\end{array}$ & $\frac{\nabla}{i}$ & 용 \\
\hline 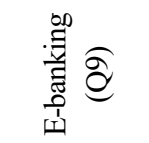 & $\frac{\hat{n}}{0}$ & $\begin{array}{l}\mathscr{n} \\
\stackrel{2}{0} \\
0\end{array}$ & 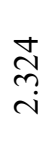 & $\begin{array}{l}\vec{d} \\
0\end{array}$ & 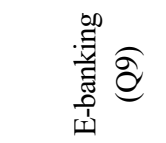 & $\frac{n}{0}$ & م̂̊. & 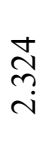 & $\begin{array}{l}\vec{\sigma} \\
0 \\
0\end{array}$ \\
\hline
\end{tabular}

Parameter is significant at the (.05) level

* * Parameter is significant at the (.01) level

$* * *$ Parameter is significant at the $(\mathbf{0 0 1 )}$ level 
Table (12) shows the regression model data for Conventional banks and Islamic banks regarding the most significant measures. This information can be represented as a regression equation as it is shown next:

$$
\begin{array}{ll}
\text { Conventional banks } & \text { Islamic banks } \\
\text { Profitability }= & \text { Profitability }= \\
0.240+0.261 \mathrm{QS}+0.327 \mathrm{Con}+0.17 & 0.663 \\
1 \mathrm{QP}+0.137 \mathrm{Ex} & +0.286 \mathrm{QS}+0.142 \mathrm{HP}+0.205 \\
& \mathrm{QP}+0170 \mathrm{EX}
\end{array}
$$

\section{Discussion}

Based on the stepwise regression there are 4 factors that lead to bank profitability via customer satisfaction in conventional and in Islamic banking in Egypt and these are as shown in table (11) Factors that are common in conventional Banks and in Islamic Banks are:

- Q4 which involves politeness and respect of customer service employees, which is a typical SERVQUAL variable, thus customers still care very much in dealing with polite courteous employees who respect them and find this an important factor for satisfaction that leads to profitability.

- Another factor is Q5 which is the availability of various bank products that will suit various customer requirements as various time deposits and various types of accounts.

- A third variable that is common in both banks is E- banking (Q9), which is becoming a major requirement that overcomes customers' time and physical limitations and allows customers to bank 24/7 with no need to physically go to the bank and stand in bank ques. E-banking could cover two of the SERVQUAL measures of Tangibles that encompass equipment and facilities as well as the knowhow by employees as to how to use these facilities (Accuracy) 
which could also touch on the service chain theory that stresses employee professionalism.

As for the factor that is different in Conventional bank it is the convenient business hours (Q7), which is also a SERVQUAL variable that represent an important issue which states that there are still customers who prefer the traditional way of banking when they go to take the bank services face to face, and thus they prefer the longer and more convenient hours and this has to be taken into consideration by conventional bank managers as such many banks are opening branches in malls which allows functioning for longer hours and on days off and this could be favored by customers.

As for the factor that is different in Islamic banking, it is High productivity of the workers (Q6), this tends to be more of a service chain variable but could be also viewed or explained as the SERVQUAL responsiveness or timely reaction of the employees to customer needs may give the impression of high productivity of workers.

\section{Financial Data}

The researchers conducted a simple financial analysis based on five profitability ratios in order to show the actual profitability of the banks (QNB Al Ahli in Conventional banks and Al Baraka Bank in Islamic banks) based on the recommendation of the banks managers. The bank managers' recommendations were collected through interviews done by the researchers in order to verify the second hypothesis and to validate the proposed profitability measures as a tool for measuring the improvement in customer satisfaction. 
Factors affecting customer satisfaction

Dr Yasser T. Halim.- Dr. Samia A. EI Sheikh 2/10/2018

Table (13): Profitability ratios for QNB Al Ahli in Conventional banks and Al Baraka Bank in Islamic banks

\begin{tabular}{|c|c|c|c|c|c|c|}
\hline \multirow[t]{2}{*}{ Ratios } & \multicolumn{3}{|c|}{$\begin{array}{c}\text { QNB (Conventional } \\
\text { banks) }\end{array}$} & \multicolumn{3}{|c|}{$\begin{array}{c}\text { Al Baraka Bank (Islamic } \\
\text { banks) }\end{array}$} \\
\hline & 2014 & 2015 & 2016 & 2014 & 2015 & 2016 \\
\hline $\begin{array}{l}\text { Return on } \\
\text { Equity }\end{array}$ & $20 \%$ & $\begin{array}{c}34.90 \\
\%\end{array}$ & $\begin{array}{c}34.61 \\
\%\end{array}$ & $\begin{array}{c}18.20 \\
\%\end{array}$ & $18 \%$ & $20 \%$ \\
\hline $\begin{array}{c}\text { Return on } \\
\text { Investment }\end{array}$ & $28 \%$ & $22 \%$ & $\begin{array}{c}21.98 \\
\%\end{array}$ & $\begin{array}{c}22.60 \\
\%\end{array}$ & $23 \%$ & $\begin{array}{c}24.23 \\
\%\end{array}$ \\
\hline $\begin{array}{l}\text { Gross Profit } \\
\text { Margin }\end{array}$ & $\begin{array}{c}44.50 \\
\%\end{array}$ & $\begin{array}{c}49.66 \\
\%\end{array}$ & $\begin{array}{c}45.50 \\
\%\end{array}$ & $\begin{array}{c}50.78 \\
\%\end{array}$ & $\begin{array}{l}50.50 \\
\%\end{array}$ & $\begin{array}{l}51.42 \\
\%\end{array}$ \\
\hline $\begin{array}{c}\text { Operating } \\
\text { Profit Margin }\end{array}$ & $\begin{array}{c}40.50 \\
\%\end{array}$ & $\begin{array}{c}41.37 \\
\% \\
\end{array}$ & $\begin{array}{c}41.15 \\
\%\end{array}$ & $\begin{array}{c}45.31 \\
\% \\
\end{array}$ & $45 \%$ & $44 \%$ \\
\hline $\begin{array}{l}\text { Net Profit } \\
\text { Margin }\end{array}$ & $\begin{array}{c}35.53 \\
\%\end{array}$ & $\begin{array}{c}34.91 \\
\%\end{array}$ & $\begin{array}{c}34.61 \\
\%\end{array}$ & $\begin{array}{c}37.80 \\
\%\end{array}$ & $\begin{array}{c}37.64 \\
\%\end{array}$ & $\begin{array}{c}39.55 \\
\%\end{array}$ \\
\hline
\end{tabular}

Table (13) shows an excellent profitability position of both banks through the three years $(2014,2015$, and 2016), and this complies with the results of the statistical parts that confirmed on the importance of the proposed measures in increasing the customer satisfaction and affect the bank profitability. Thus $\mathbf{H 2}$ is accepted

\section{8-Conclusion}

To sum up the following was reached by the researchers:

1-Some of the proposed measures presented by the researchers have been approved as a valid way of improving profitability through enhancing the customer satisfaction in banks both in Conventional banks and Islamic banks as follows:

- Not all the financial measures for measuring customer satisfaction that were proposed by researchers based on their interviews with bank managers have been approved as a way of measuring the customer satisfaction in the banking sector. In fact, the interest rates and cost of services offered are among the factors of high loading in CFA. 
- Of the service chain theory only one factor happens to be highly important and leads to satisfaction of customers which is High productivity of the workers.

- Most of the SERVQUAL factors are highly important for customer satisfaction. This support the theoretical base of SERVQUAL theory which is still very valid with a few additions.

- The statistical analysis filtered the proposed measures to present the fit of financial measures for customer satisfaction in Conventional banks and Islamic banks.

2-The statistical analysis showed the significant relation between profitability and customer satisfaction. Moreover, the stepwise regression identified the factors that lead to highest profitability, These included factors that are common in conventional Banks and in Islamic Banks as politeness and respect of customer service employees, which is a typical SERVQUAL variable, thus customers still care very much in dealing with polite courteous employees who respect them and find this an important factor for satisfaction that leads to profitability. Another factor is the availability of various bank products that will suit various customer requirements as various time deposits and various types of accounts. A third variable that is common in both banks is E- banking, which is becoming a major requirement that overcomes customers' time and physical limitations and allows customers to bank $24 / 7$ with no need to physically go to the bank and stand in bank ques. E-banking could cover two of the SERVQUAL measures of Tangibles that encompass equipment and facilities as well as the knowhow by employees as to how to use these facilities (Accuracy) which could also touch on the service chain theory that stresses employee professionalism. It is advisable for bank managers to take into consideration that most upcoming generations will be more likely to resort to E-banking as the younger generations are more comfortable in dealing with technology. 
As for the factor that is different in Conventional bank it is the convenient business hours which is also a SERVQUAL variable that represent an important issue which states that there are still customers who prefer the traditional way of banking when they go to take the bank services face to face, and thus they prefer the longer and more convenient hours and this has to be taken into consideration by conventional bank managers as such many banks are opening branches in malls which allows functioning for longer hours and on days off and this could be favored by customers.

As for the factor that is different in Islamic banking, it is High productivity of the workers, this tends to be more of a service chain variable but could be also viewed or explained as the SERVQUAL responsiveness or timely reaction of the employees to customer needs may give the impression of high productivity of workers.

3-The financial information verified hypothesis two through the interview with banks managers and the recommendations by them that the improvement of the customer service through the proposed measures can affect the bank profitability and that the financial ratios presented above are a valid way to measure the effect of improvement in customer satisfaction and maximization of banks profit in Conventional banks and Islamic banks.

\section{9-Research limitations}

The results of the research are based on a limited number of surveys that has been distributed to the clients of one private bank in Great Cairo region QNB AL Ahli Bank and another private Islamic bank in Cairo region (Al Baraka Bank) as they are among the reputable private banks there. Thus the study does not include and does not separate the sample into various geographical areas of Egypt. Our research was targeting two hundred and forty bank customers in each bank and six bank managers in Cairo but we managed to interview only four managers. By nature of case studies, the results cannot be generalized but they give useful insight into the topic under study. It is recommended that further research is necessary to establish the exact nature of the causal linkages between proposed customer satisfaction 
measures and bank profitability. On the professional level, this research could help strategic managers to gain insights into the factors that would lead to customer satisfaction and thus to bank profitability.

Al Baraka Bank Egypt web site <www.albarakabank.com.eg/about/.aspx>

Anderson, E.W. and Mittal, V. (2000), Strengthening the SatisfactionProfit Chain, Journal of Service Research, Vol. 3 No. 2, pp. 10720.

Anderson, E.W., Fornell, C., and Mazvancheryl, S.K. (2004), Customer Satisfaction and Shareholder Value, Journal of Marketing, Vol. 68, Pp. 172-185.

Angel M. Gento, M. Dolores Minambres, Alfonso Redondo t, M. Elena Perez (2001). QFD Application in a Service Environment: A New Approach in Risk Management in a University, Operational Research, an International Journal.Vol.1, No.2 Pp. 115-132.

Bennet, R. (1992), The Customer-Driven Competitive Edge, Bank Marketing, Pp.50-51.

Bowen, J.W. and Hedges, R.B. (1993), Increasing Service Quality in Retail Banking, Journal of Retail Banking, 15, 21-28.

Central Bank of Egypt, (2016/2017), Annual Review Report. $<$ www.cbe.com.eg>

Daire, H., Joseph, C., Michael, R. and Mullen, (2008), Structural Equation Modeling: Guidelines for Determining Model Fit, Journal of Business Research Methods, Volume 6 Issue 12008.

Deng, Z., Lu, Y, Wei, K. K., Zhang, J. (2009), Understanding Customer Satisfaction and Loyalty: An Empirical Study of Mobile Instant Messages in China, International Journal of Information Management, Vol. 30, pages 289-300. 

Satisfaction, The TQM Magazine, Vol. 16 No. 1, pp. 57-66.

Fisher, A. (2001). Winning the Battle for Customers, Journal of Financial Services Marketing, 6(1), September, pp. 77-84.

Fong, C., Lee, G., Lee, E., Kubota, C., and Allen, Ch. (2007), Structural Equation Modeling in Rehabilitation Counseling Research, Rehabilitation Counseling Bulletin, 51: 1, 2007.

Govind J. (March 2009), Customer Satisfaction in General Insurance Industry - A Step Towards Competitiveness, A Journal of Risk \& Insurance Pravartak, Vol. IV Issue 3.

Gro"nroos, C. (1984), A Service Quality Model and Its Marketing Implications, European Journal of Marketing, Vol. 18 No. 4, pp. 36-44.

Gustafsson, A., Johnson, M.D., and Roos, I. (2005), The Effects of Customer Satisfaction, Relationship Commitment Dimensions, and Triggers on Customer Retention, Journal of Marketing, Vol. 69, pg. 210-218.

Hansemark, O.C. and Albinsson, M. (2004), Customer Satisfaction and Retention: The Experience Of Individual Employees, Managing Service Quality, Vol. 14 No. 1, pp. 40-57.

Hair, J. F., Black, W.C., Babin, B.J. and Anderson, R.E. (2010), Multivariate Data Analysis : a global perspective, $7^{\text {th }}$ Edition, New Jersey: Pearson Education Inc.

Harry Maddern, Roger Maull, Andi Smart, and Paul Baker.(2007), Customer Satisfaction And Service Quality In UK Financial Services, International Journal of Operations \& Production Management Vol. 27 No. 9, pp. 998-1019. Emerald Group Publishing Limited 0144-3577. 

Determinants of Islamic banking profitability,ERF Paper, in Proceedings of the ERF 10th Annual Conference, Marrakesh, Morocco.

Heskett, J.L., Jones, T.O., Loveman, G.W., Sasser, W.E. Jr. and Schlesinger, L.A. (1994), Putting the Service-Profit Chain to Work, Harvard Business Review, March/April, pp. 164-74.

Ittner, C., \& Larcker, D.F., (1998). Are Non-financial Measures Leading Indicators of Financial Performance? An Analysis of Customer Satisfaction, Journal of Accounting Research, 2, 138-144.

Kotler, P., Keller K.L., (2012), A Framework for Marketing Management (Fifth Ed. Edinburgh Gate, England: Pearson Education Limited. p82.

Leeds, B. (1992). Mystery Shopping' Offers Clues to Quality Service, Bank Marketing, 24(11), November, pp. 24-27.

Levesque, T. and McDougall, G.H.G., (1996), Determinants of Customer Satisfaction in Retail Banking, International Journal of Bank Marketing, Vol. 14 No. 7, pp. 12-20.

Loveman, G.W. (1998), Employee Satisfaction, Customer Loyalty, and Financial Performance: An Empirical Examination of The Service Profit Chain in Retail Banking, Journal of Service Research, Vol. 1 No. 1, pp. 18-31.

Magnus Söderlund\& Mats Vilgon (January, 1999) Customer Satisfaction and Links to Customer Profitability: An Empirical Examination of the Association between Attitudes and Behavior, SSE/EFI Working Paper Series in Business Administration No. 1999:1.

Marvin E., Gonza' lez., Gioconda Quesada, Federico Picado, and Carl A. Eckelman (2004), Customer Satisfaction using QFD: an e-banking Case., Managing Service Quality, Volume $14 \cdot$ Number 4· pp. 317-330 q Emerald Group Publishing Limited· ISSN 0960-4529. 
Miguel I. Gomeza, Edward W. McLaughlinb, Dick R. Wittinkc (2004), Customer Satisfaction and Retail Sales Performance: An Empirical Investigation, Journal of Retailing 80 265-278.

Muhammad SaifuddinKhondaker and Monir Z. Mir (September 2011), Customer Satisfaction Measurement for State Owned Banks in Least Developed Types - A Case Of Bangladesh, Journal of Business and Policy Research, Vol. 6. No.2.Special Issue. pp. 153-172.

Newman, K. and Cowling, A. (1996), Service Quality in Retail Banking: The experience of Two British Clearing Banks, International Journal Of Bank Marketing, pp. 41-50.

Oliver, R.L., (1980) A Cognitive Model of The Antecedents and Consequences of Satisfaction Decisions, Journal of Marketing Research, Vol. XVII, November.

Parasuraman, A., Zeithmal, V.A. and Berry, L.L. (1985), A Conceptual Model of Service Quality and Its Implications For Future Research, Journal of Marketing, Vol. 49, pp. 40-50.

Peppers, D. and Rogers, M. (1993), The One to One Future: Building Relationships One Customer at a Time, Currency/Doubleday, New York, NY

Qatar National Bank Al Ahli (QNB Al Ahil) web site $<$ www.qnbalahli.com $>$

Reaz, M., Arun, T. (2006), Corporate Governance in Developing Economies: Perspective from the Banking Sector in Bangladesh, Journal of Banking Regulation, Vol. 7 No.1/2, pp.94-105.

Reza, S. M Nasserzadeh, M. HamedJafarzadeh, Taha Mansouri, and BabakSohrabi (2008), Customer Satisfaction Fuzzy Cognitive Map in Banking Industry, Communications of the IBIMA Volume 2. 

Advantage, Bank Management. 14-19.

ShahrilShafie, Wan Nursofiza Wan Azmi, Sudin Haron (2004). Adopting And Measuring Customer Service Quality In Islamic Banks: A Case Study of Bank Islam Malaysia Berhad. The Journal of Muamalat and Islamic Finance Research, Vol. 1, No.1).

Storbacka K., Strandvik T \& Grönroos C, (1994), Managing Customer Relationships for Profit: The Dynamics of Relationship Quality, International Journal of Service Industry Management, Vol. 5, No. 5, 21-38.

Zairi, M. (1997), Business Process Management: A Boundaryless Approach to Modern Competitiveness, Business Process Management Journal, Vol. 3 No. 1, pp. 64-8.

Zoe S. Dimitriades (2006), Customer Satisfaction, Loyalty and Commitment in Service Organizations Some Evidence From Greece, Management Research News Vol. 29 No. 12, pp. 782-800 Emerald Group Publishing Limited 0140-9174 